\title{
Correlation Studies of Growth and Flowering of Dendrobium cv. Sonia with Microclimatic Variables in Different Protected Structures
}

\author{
Punam Saikia*, Pradip Mahanta and Rajib Lusan Deka \\ Department of Horticulture, Assam Agricultural University Jorhat, Assam-785013, India \\ *Corresponding author
}

\begin{tabular}{|l|}
\hline Ke y w o r d s \\
Correlation, \\
Dendrobium, \\
Growth, Flowering, \\
Microclimate, \\
Protected structure
\end{tabular}

\section{A B S T R A C T}

The present investigation entitled "Correlation studies of growth and flowering of Dendrobium cv. Sonia with microclimatic variables in different protected structures" was conducted in the Experimental Farm, Department of Horticulture, Assam Agricultural University, Jorhat during 2017-2018. The experiment was laid out with 5 treatments replicated three times viz. $\mathrm{G}_{1}$ (Bamboo frame structure covered with fixed 200 micron UV film with top ventilated and $50 \%$ agro shade net as ceiling), $\mathrm{G}_{2}$ (Bamboo frame structure with fixed 50\% agro shade net as cladding material), $\mathrm{G}_{3}$ (Bamboo frame structure covered with fixed 200 micron UV film with side removable and 50\% agro shade net as ceiling), $\mathrm{G}_{4}$ (Bamboo frame structure with fixed 50\% agro shade net and 200 micron UV film as top covering) and $\mathrm{G}_{5}$ (Bamboo frame structure with 200 micron UV film side removable and fixed 50\% agro shade net as covering). It was observed that all the microclimatic parameters of protected structures were found to be lower than the open field condition. The highest maximum and minimum temperature were found in $\mathrm{G}_{3}$ while the highest morning and evening humidity were found in $\mathrm{G}_{2}$ during 2017 and 2018, respectively. The highest average light intensity was found in $\mathrm{G}_{1}$. It was found that all the growth characters highly correlated with maximum temperature and minimum temperature under $G_{1}$ condition. For flower characters mean microclimatic parameters calculated from 5 different phenophases viz. $\mathrm{PP}_{1}$ (planting to bud visibility), $\mathrm{PP}_{2}$ (planting to full bloom), $\mathrm{PP}_{3}$ (bud visibility to opening of first floret), $\mathrm{PP}_{4}$ (bud visibility to full bloom) and $\mathrm{PP}_{5}$ (opening of first floret to full bloom). The highest negative correlation coefficient of most of the flower characters was found at $\mathrm{PP}_{1}$ and $\mathrm{PP}_{4}$ phase in respect of maximum temperature and minimum temperature.

\section{Introduction}

Dendrobiums are most popular tropical orchid getting fame as cut flowers in India as well as in the world. It comprises approximately 1200-1500 species and more than thousand types of hybrids in the world. The total orchid cut flower trade of the world mostly consists of 70-80 per cent Dendrobium species (Cheamuangphan and Panmanee, 2013). About 103 species of Dendrobium orchids are reported from India (Singh et al., 2001). Out of them, 82 species are from North East Region. Dendrobium cv. Sonia flowered 
throughout the year with peak flowering during August to October and March to June under North East Region. Dendrobium orchids are specialty flowers and require special attention during cultivation. Dendrobium grows best at night temperatures between $15-18^{\circ} \mathrm{C}$ and day temperatures 23 $29^{0} \mathrm{C}$. They prefer $60-80$ per cent of relative humidity. They grow well both in tropical and subtropical climate and require warm bright light (25,000-30,000 lux) as well as good ventilation. Therefore, Dendrobiums are grown under protected condition for both plant sale and cut flowers production. But, in North East India, Dendrobium orchids are normally grown under shade net houses which are quite vulnerable to cold injury during extreme winter period which causes severe impediment in growth and flowering. Therefore, attention should be given to the climate demands of flowers grown to allow achieving better productivity and high quality flowers according to the consumer preference. Hence, the present investigation is aimed to study the correlation of growth and flowering habit of Dendrobium cv. Sonia with microclimatic variables in different protected structures.

\section{Materials and Methods}

The present investigation entitled "Correlation studies of growth and flowering of Dendrobium cv. Sonia with microclimatic variables in different protected structures" was conducted in the Experimental Farm, Department of Horticulture, Assam Agricultural University, Jorhat during the period of 2017-2018 for two seasons. The experiment was laid out in Completely Randomized Design with 5 treatments replicated three times viz. $\mathrm{G}_{1}$ (Bamboo frame structure covered with fixed 200 micron UV film with top ventilated and 50\% agro shade net as ceiling), $\mathrm{G}_{2}$ (Bamboo frame structure with fixed $50 \%$ agro shade net as cladding material), $\mathrm{G}_{3}$ (Bamboo frame structure covered with fixed 200 micron UV film with side removable and $50 \%$ agro shade net as ceiling), $\mathrm{G}_{4}$ (Bamboo frame structure with fixed 50\% agro shade net and 200 micron UV film as top covering), $\mathrm{G}_{5}$ (Bamboo frame structure with 200 micron UV film side removable and fixed $50 \%$ agro shade net as covering). These were oriented in NorthSouth direction with a size of $4 \mathrm{~m}$ length, $4 \mathrm{~m}$ width and central height of $3 \mathrm{~m}$. Plantlets were planted in the plastic basket of size 6" depth and 4" diameter and basket was filled laying 1" at the top with a mixture of charcoal, coco husk and coco peat. These were arranged at the rate of 20 plants on bamboo bench at a size of $1 \mathrm{~m}$ breath and $3 \mathrm{~m}$ length. Fertilizer mixture NPK- 19:19:19 @ $2 \mathrm{~g} / \mathrm{L}$ was given twice a week as foliar spray. All the observations were recorded for two growing season i.e. 2017 and 2018. Karl Pearson's correlation coefficient (r) was calculated and the test of significance was applied as per the procedure outlined by Fisher and Yates (1963).

\section{Results and Discussion}

\section{Microclimatic variation}

The meteorological data viz. maximum (Tmax) and minimum (Tmin) temperature, morning (RH I) and evening (RHII) relative humidity, light intensity were recorded in daily basis and monthly mean values were computed (Table 1-5).

\section{Temperature $\left({ }^{0} \mathrm{C}\right)$}

Prevalence of high maximum temperature was more pronounced under open field condition. Further, amongst the growing structures, $\mathrm{G}_{3}$ exhibited the highest average maximum and minimum temperature as compared to the others. The lowest minimum temperature was observed on January during 2017 and 2018, respectively (Fig. 1 and 2). 


\section{Relative humidity (\%)}

It was observed that relative humidity inside the growing structures was always less than the open field condition. In case of protected structures, the highest morning relative humidity was found on January whereas the lowest morning relative humidity was observed on May during 2017 as well as on April during 2018 (Fig. 3 and 4). The highest evening relative humidity was found during the months of July to August. The lowest evening relative humidity was observed on February for both years. The highest average relative humidity irrespective of the microclimatic regimes was found in $\mathrm{G}_{2}$.

\section{Light intensity (lux)}

It was observed that relative humidity inside the growing structures was always less than the open field condition. A glance at the monthly light intensity graph showed that the highest average light intensity was found in $\mathrm{G}_{1}$ followed by $\mathrm{G}_{4}$ for both the years. The highest light intensity was observed on February as well as the lowest one on August in different growing structures for both the years (Fig. 5).

\section{Growth characters}

The growth characters and microclimatic parameters were subjected to correlation analysis based on five protected structures namely $\mathrm{G}_{1}, \mathrm{G}_{2}, \mathrm{G}_{3}, \mathrm{G}_{4}$ and $\mathrm{G}_{5}$.

The data explained that plant height was highly influenced by microclimatic parameters showing highest positive significant correlation coefficient in respect of maximum temperature (0.629) of $\mathrm{G}_{2}$ as well as minimum temperature (0.551) of $\mathrm{G}_{1}$ treatment. On the other hand, light intensity was negatively correlated with plant height in most of the treatments. It was found that leaves per plant had positive and significant correlation with maximum temperature (0.632) of $\mathrm{G}_{2}$ whereas minimum temperature (0.560) and light intensity (0.317) of $\mathrm{G}_{1}$ treatment. There was negative correlation between relative humidity and leaves per plant under the growing structures. Leaf area per plant was also positively correlated with maximum temperature and minimum temperature. Highest positive correlation coefficient was obtained in respect of maximum temperature (0.666) of $\mathrm{G}_{2}$ while minimum temperature $(0.592)$ of $\mathrm{G}_{4}$ treatments. Height of pseudobulb was positively correlated with maximum temperature and minimum temperature. Highest correlation coefficient was obtained in respect of maximum temperature $(0.630)$ under $\mathrm{G}_{2}$ while minimum temperature (0.584) under $\mathrm{G}_{1}$.Pseudobulbs per plant was also positively correlated with maximum temperature and minimum temperature. Highest positive correlation coefficient was obtained in respect of maximum temperature $(0.462)$ and light intensity (0.552) corresponding to the treatment $\mathrm{G}_{1}$.

The results indicate that correlation for all growth characters was found highly significant. The possible reason is that the control of the microclimatic variables inside the protective structure is an extremely dynamic process. Most of the climatic parameters dependent on the ventilation rate, shading which in turn were either due to buoyancy effect or by wind effect or both. In the present study, $G_{1}$ (Bamboo frame structure covered with fixed 200 micron UV film with top ventilated and 50\% agro shade net as ceiling) was found to be superior among growing structures. This phenomenon could be attributed to the favorable environmental conditions viz., optimum temperature, relative humidity, light intensity and proper air circulation inside the growing system which may drastically influence the 
growth of the plants. Similar findings have been reported by Zou and Liu (2010) and Taiz and Zieger (2002).

\section{Flower characters}

Correlation of different flower characters with microclimatic parameters at 5 different phonological phases viz. $\mathrm{PP}_{1}$ (planting to bud visibility), $\mathrm{PP}_{2}$ (planting to full bloom), $\mathrm{PP}_{3}$ (bud visibility to opening of first floret), $\mathrm{PP}_{4}$ (bud visibility to full bloom) and $\mathrm{PP}_{5}$ (opening of first floret to full bloom) in respect of different crop growth stages.

Spikes per plant were negatively or positively correlated with most of the microclimatic parameters at different phonological phases. The results revealed that spikes per plant was highly influenced by microclimatic parameters showing highest significant correlation coefficient in respect of minimum temperature (-0.933) during $\mathrm{PP}_{1}$ phenophase followed by $\mathrm{PP}_{3}$. The correlation for spike length was found highly significant at different phenophase, but negatively correlated with maximum temperature ($0.558)$ and minimum temperature $(-0.872)$ during $\mathrm{PP}_{1}$ phenophase followed by $\mathrm{PP}_{3}$. Florets per plant was highly influenced by microclimate showing highest significant correlation coefficient in respect of maximum temperature (-0.654) and minimum temperature $(-0.842)$ during $\mathrm{PP}_{1}$ phenophase followed by $\mathrm{PP}_{5}$.

Floret diameter was highly influenced by minimum temperature (-0.856), light intensity $(-0.837)$ showing highest negative significant correlation coefficient during $\mathrm{PP}_{4}$. Shelf life of spike was highly influenced by maximum temperature (-0.734) and minimum temperature (-0.591) showing highest negative significant correlation coefficient at $\mathrm{PP}_{2}$ phenophase whereas positively correlated with evening relative humidity $(0.866)$ at $\mathrm{PP}_{4}$ phenophase. Similarly, vase life was positively correlated with evening relative humidity (0.842) during $\mathrm{PP}_{4}$ followed by $\mathrm{PP}_{5}$ (0.814) phenophase.

It was evident that flower quality and yield highly influence by microclimatic variables. This might be due to that the flower induction is a complex systemic process regulated by numerous genes, promoters and inhibitors, which are triggered by various signals, such as photoperiod and temperature. High temperature (above 25-30 ${ }^{0} \mathrm{C}$ ) experienced during the period when flower induction and initiation normally occur also delays them, but under these conditions, the flowering capacity of plants is maintained.

But, too low temperature reduced the respiration and other biochemical activities, as well as the length of stem and number of flowers, which are considered the main parameters for cut stem grading. From the data it was observed that with the onset of spring in March, there was a rise in temperature, which breaks the vegetative dormancy set in the winter and induces flowering in many Dendrobium. Correlation between light intensity and flowering showed that light intensity during flower initiation affected the flower or plant quality. Sayed (2001) also reported similar effect of temperature on Phalaenopsis and Robinson (2002) observed that air temperature has high correlation with quality of the flowers.

In conclusion, better growth, development and yield of flower were achieved under $G_{1}$ due to the higher (optimum) temperature and lower relative humidity during the winter months (January to February) and lower temperature and relatively higher relative humidity during summer month (March to May), so growers are benefited by being able to produce higher yield and quality which fetched premium prices in the market. 
Table.1 Correlations between microclimatic parameters and plant height and leaves per plant of Dendrobium cv. Sonia (mean over two years)

\begin{tabular}{|c|c|c|c|c|c|c|c|c|c|c|}
\hline \multirow{2}{*}{$\begin{array}{l}\text { Microclimatic } \\
\text { parameters }\end{array}$} & \multicolumn{5}{|c|}{ Plant height $(\mathrm{cm})$} & \multicolumn{5}{|c|}{ Leaves per plant } \\
\hline & $\mathrm{G}_{1}$ & $\mathrm{G}_{2}$ & $\mathrm{G}_{3}$ & $\mathrm{G}_{4}$ & $\mathrm{G}_{5}$ & $\mathrm{G}_{1}$ & $\mathrm{G}_{2}$ & $\mathrm{G}_{3}$ & $\mathrm{G}_{4}$ & $\mathrm{G}_{5}$ \\
\hline Tmax & $0.584 * *$ & $0.629 * *$ & $0.525^{*}$ & $0.582 * *$ & $0.582 * *$ & $0.614 * *$ & $0.632 * *$ & $0.551^{*}$ & $0.598 * *$ & $0.599 * *$ \\
\hline Tmin & $0.551^{*}$ & $0.511^{*}$ & $0.468 *$ & $0.524 *$ & $0.502 *$ & $0.560 *$ & $0.511^{*}$ & $0.477^{*}$ & $0.537 *$ & $0.521 *$ \\
\hline RH I & 0.050 & -0.170 & -0.175 & -0.062 & 0.268 & -0.026 & -0.251 & -0.129 & -0.124 & 0.172 \\
\hline RH II & 0.021 & 0.122 & -0.189 & -0.037 & 0.082 & 0.045 & 0.164 & -0.161 & 0.007 & 0.128 \\
\hline Light intensity & 0.344 & $-0.827 * *$ & $-0.829 * *$ & 0.249 & $-0.524 *$ & $0.317 *$ & $-0.800 *$ & $-0.750 * *$ & $0.220 *$ & -0.482 \\
\hline
\end{tabular}

Table.2 Correlations between microclimatic parameters and leaf area per plants and height of pseudobulb of Dendrobium cv. Sonia

\begin{tabular}{|c|c|c|c|c|c|c|c|c|c|c|}
\hline \multirow{2}{*}{$\begin{array}{l}\text { Microclimatic } \\
\text { parameters }\end{array}$} & \multicolumn{5}{|c|}{ Leaf area per plant $\left(\mathrm{cm}^{2}\right)$} & \multicolumn{5}{|c|}{ Height of pseudobulb(cm) } \\
\hline & $\mathrm{G}_{1}$ & $\mathrm{G}_{2}$ & $\mathrm{G}_{3}$ & $\mathrm{G}_{4}$ & $\mathrm{G}_{5}$ & $\mathrm{G}_{1}$ & $\mathrm{G}_{2}$ & $\mathrm{G}_{3}$ & $\mathrm{G}_{4}$ & $\mathrm{G}_{5}$ \\
\hline Tmax & $0.612 * *$ & $0.666 * *$ & $0.571 * *$ & $0.641 * *$ & $0.636 * *$ & $0.598 * *$ & $0.630 * *$ & $0.579 * *$ & $0.606 * *$ & $0.605^{* *}$ \\
\hline Tmin & $0.586 * *$ & $0.533 *$ & $0.502 *$ & $0.592 * *$ & $0.574 * *$ & $0.584 * *$ & $0.524 *$ & $0.534 *$ & $0.563 * *$ & $0.542 *$ \\
\hline RH I & 0.067 & -0.145 & -0.138 & -0.090 & 0.261 & 0.078 & -0.091 & -0.111 & -0.05 & 0.280 \\
\hline RH II & 0.041 & 0.155 & -0.215 & -0.046 & 0.066 & 0.041 & 0.144 & -0.233 & -0.100 & -0.009 \\
\hline $\begin{array}{l}\text { Light } \\
\text { intensity }\end{array}$ & 0.287 & $-0.781 *$ & $-0.714 * *$ & 0.132 & -0.496 & 0.374 & $-0.806^{* *}$ & $-0.800 * *$ & 0.246 & $-0.548 *$ \\
\hline
\end{tabular}

Table.3 Correlation coefficient of microclimatic parameters at different phenophases with spikes per plant and spike length of Dendrobium cv. Sonia (mean over two years)

\begin{tabular}{|c|c|c|c|c|c|c|c|c|c|c|}
\hline \multirow{2}{*}{$\begin{array}{c}\text { Microclimatic } \\
\text { parameters }\end{array}$} & \multicolumn{5}{|c|}{ Spikes per plant } & \multicolumn{5}{|c|}{ Spike length(cm) } \\
\hline & $\mathrm{PP}_{1}$ & $\mathrm{PP}_{2}$ & $\mathrm{PP}_{3}$ & $\mathrm{PP}_{4}$ & $\mathrm{PP}_{5}$ & $\mathrm{PP}_{1}$ & $\mathrm{PP}_{2}$ & $\mathrm{PP}_{3}$ & $\mathrm{PP}_{4}$ & $\mathrm{PP}_{5}$ \\
\hline T max & -0.605 & -0.337 & -0.588 & -0.565 & -0.436 & $-0.558^{*}$ & -0.279 & -0.473 & -0.493 & -0.380 \\
\hline $\mathbf{T} \min$ & $-0.933^{* * *}$ & -0.498 & $-0.837^{* * *}$ & $-0.811^{* *}$ & -0.522 & $-0.872 * *$ & -0.504 & $-0.833^{* * *}$ & $-0.817 * *$ & -0.454 \\
\hline RH I & -0.325 & -0.297 & -0.144 & 0.029 & 0.238 & -0.308 & -0.281 & -0.142 & 0.019 & 0.234 \\
\hline RH II & -0.251 & -0.134 & 0.043 & 0.040 & 0.071 & -0.252 & -0.105 & 0.099 & 0.116 & 0.184 \\
\hline $\begin{array}{c}\text { Light } \\
\text { intensity }\end{array}$ & -0.241 & -0.298 & -0.299 & -0.271 & -0.545 & -0.113 & -0.191 & -0.263 & -0.262 & $-0.681^{*}$ \\
\hline
\end{tabular}


Table.4 Correlation coefficient of microclimatic parameters at different phenophases with florets per spike and floret diameter of Dendrobium cv.Sonia (mean over two years)

\begin{tabular}{|c|c|c|c|c|c|c|c|c|c|c|}
\hline \multirow{2}{*}{$\begin{array}{l}\text { Microclimatic } \\
\text { parameters }\end{array}$} & \multicolumn{5}{|c|}{ Florets per spike } & \multicolumn{5}{|c|}{ Floret diameter $(\mathrm{cm})$} \\
\hline & $\mathrm{PP}_{1}$ & $\mathrm{PP}_{2}$ & $\mathrm{PP}_{3}$ & $\mathrm{PP}_{4}$ & $\mathrm{PP}_{5}$ & $\mathrm{PP}_{1}$ & $\mathrm{PP}_{2}$ & $\mathrm{PP}_{3}$ & $\mathrm{PP}_{4}$ & $\mathrm{PP}_{5}$ \\
\hline T max & $-0.654 *$ & -0.454 & $-0.613 *$ & -0.610 & -0.454 & -0.471 & -0.284 & -0.472 & -0.481 & -0.332 \\
\hline $\mathbf{T}$ min & $-0.842 * *$ & -0.567 & $-0.847^{* *}$ & $-0.864 * *$ & $-0.594 *$ & $-0.829 * *$ & $-0.615^{*}$ & $-0.856^{* *}$ & $-0.856 * *$ & $-0.558 *$ \\
\hline RH II & -0.083 & 0.048 & 0.214 & 0.224 & 0.229 & -0.228 & -0.090 & 0.106 & 0.105 & 0.136 \\
\hline Light intensity & -0.290 & -0.346 & -0.306 & $-0.866 * *$ & $-0.582 *$ & -0.251 & -0.310 & -0.279 & $-0.837 * *$ & $-0.650^{*}$ \\
\hline
\end{tabular}

Table.5 Correlation coefficient of microclimatic parameters at different phenophases with shelf life and vase life of Dendrobium cv.Sonia (mean over two years)

\begin{tabular}{|c|c|c|c|c|c|c|c|c|c|c|}
\hline \multirow{2}{*}{$\begin{array}{c}\text { Microclimatic } \\
\text { parameters }\end{array}$} & \multicolumn{9}{|c|}{ Shelf life of spike (days) } & \multicolumn{4}{c|}{ Vase life of spike (days) } \\
\hline T max & -0.464 & $-0.734_{1}^{*}$ & -0.441 & -0.552 & -0.464 & $-0.616^{*}$ & -0.405 & $-0.556^{*}$ & -0.569 & -0.431 \\
\hline T min & 0.039 & -0.600 & -0.460 & -0.585 & $-0.591^{*}$ & $-0.836^{* *}$ & $-0.624^{*}$ & $-0.894^{* *}$ & $-0.896^{* *}$ & $-0.572^{*}$ \\
\hline RH I & 0.470 & 0.570 & 0.536 & 0.541 & 0.476 & -0.222 & -0.162 & 0.029 & 0.138 & 0.346 \\
\hline RH II & $0.768^{* *}$ & $0.840^{* *}$ & 0.807 & $0.866^{* *}$ & $0.785^{* *}$ & -0.117 & 0.042 & 0.232 & 0.270 & 0.341 \\
\hline Light intensity & -0.080 & -0.085 & 0.030 & -0.223 & -0.191 & -0.139 & -0.215 & -0.284 & $-0.817 * *$ & $-0.634^{*}$ \\
\hline
\end{tabular}


Fig.1 Monthly temperature $\left({ }^{\circ} \mathrm{C}\right)$ variation in different growing structures and open field during 2017

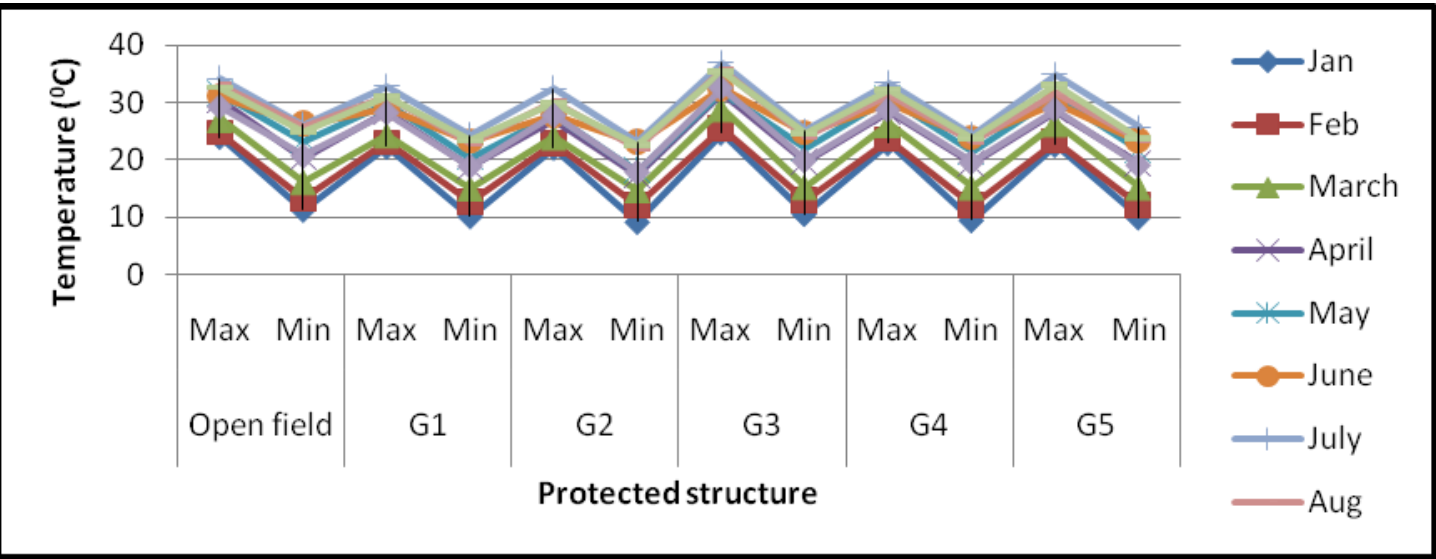

Fig.2 Monthly temperature variation $\left({ }^{\circ} \mathrm{C}\right)$ in different growing structures and open field during 2018

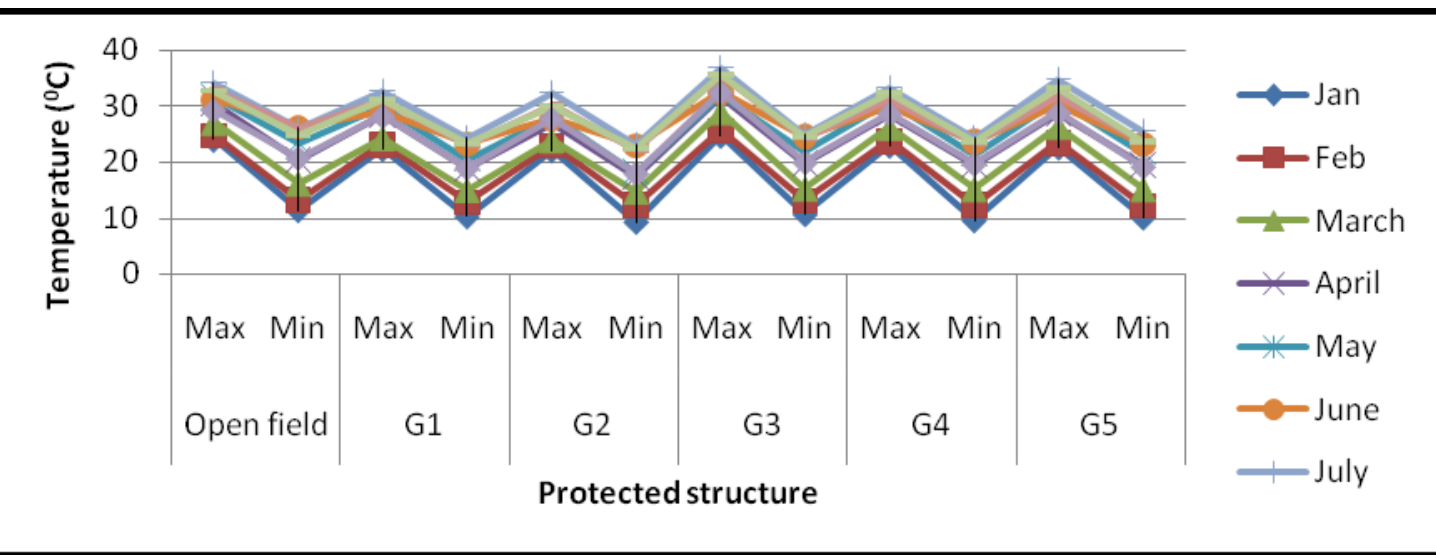

Fig.3 Monthly humidity (\%) variation in different growing structures and open field during 2017

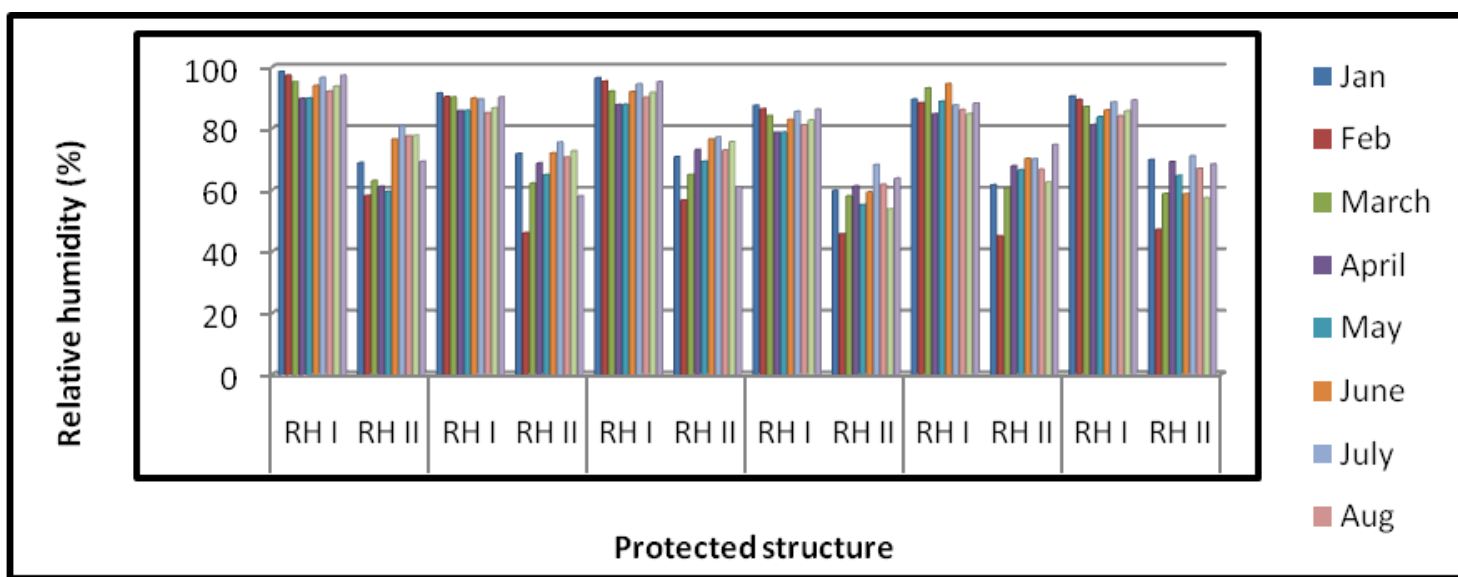


Fig.4 Monthly humidity (\%) variation in different growing structures and open field during 2018

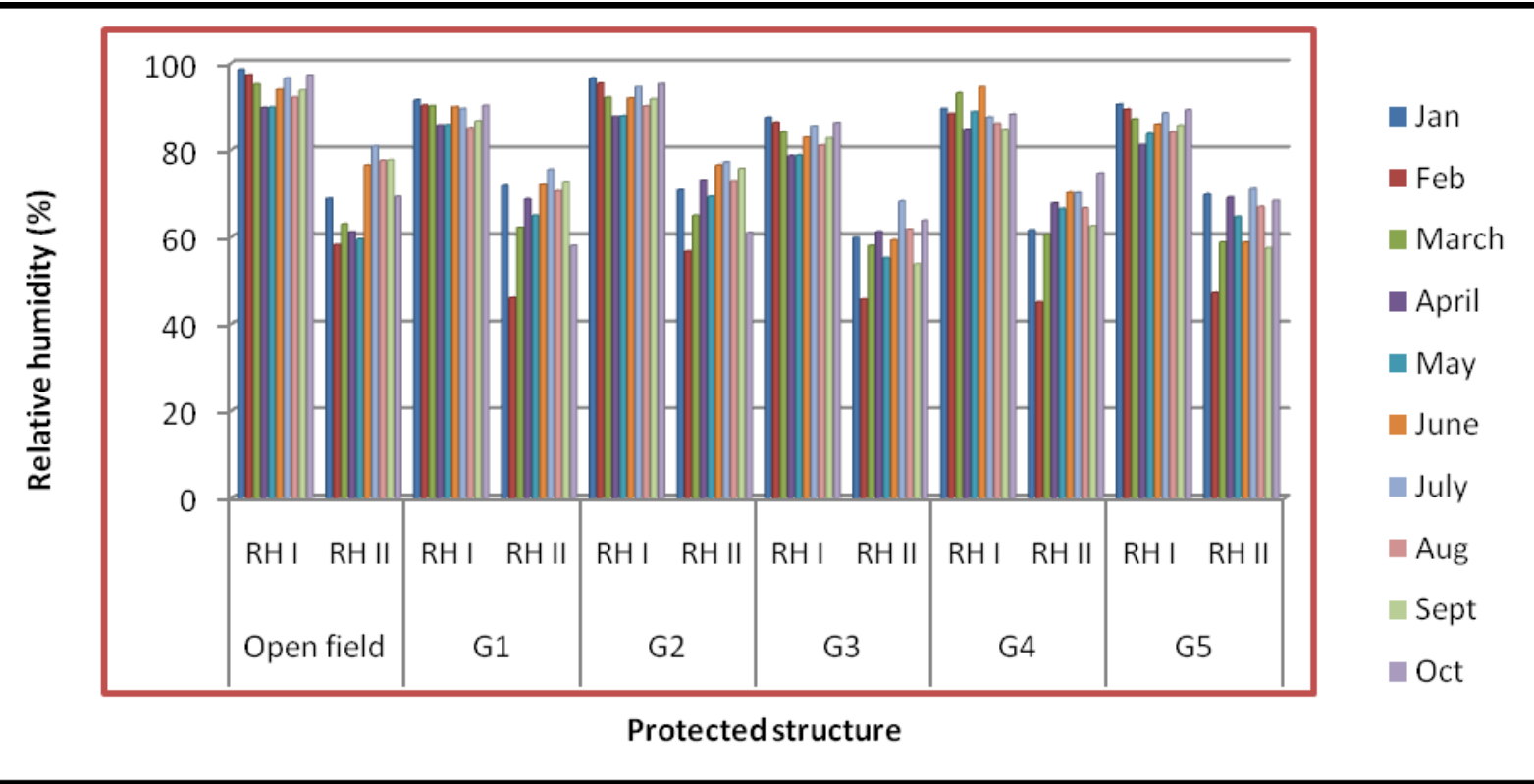

Fig.5 Monthly light intensity (lux) variation in different growing structures and open field during 2017-2018

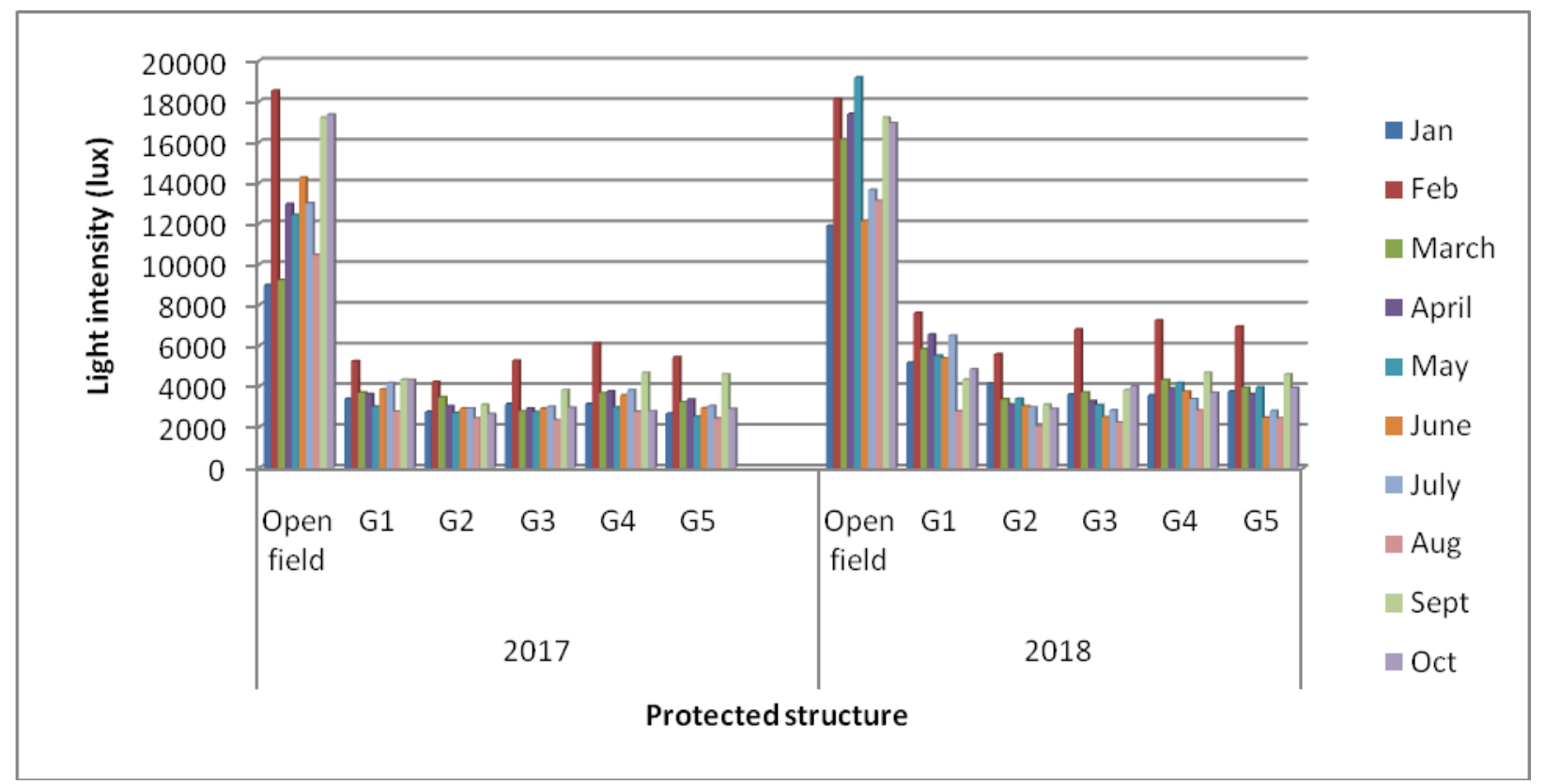

This information indicated that the study of correlation among various climatic variables and growth and flower characters are an important aspect for better planning of selection programs and choice of protected system can be effective tool for the yield improvement of Dendrobium cv. Sonia. Microclimatic parameters play a unique role in the growth and development of Dendrobium orchids. So, the environment control of greenhouse is necessary to achieve a reasonable spatial distribution of the desired 
temperature, relative humidity and light intensity for crop growth.

\section{References}

Cheamuangphan, A., Panmanee, C. and Tanusuchat, R. 2013.Value chain Analysis for orchid cut flower business in Chiang Mai. Business and information, 7-9.

Fisher, R.A. and Yates, F., 1963. Statistical tables for Biological, Agricultural and Medical research. Oliver and Boyd Ltd., Edin burgh.

Robinson, K.A. 2002. Effect of temperature on the flower development rate and morphology of Phalaenopsis orchid. MS thesis. Mich. State Univ. East Lansing. Sayed, O. H. 2001. Crassulacean Acid Metabolism a check list, Photosynthetica 5:748-754.

Singh, K.P., Phukan, S. and Bujarbarua, P. (2001). Floristic Diversity and Conservation Strategies in India. Bot. Surv. Ind., 4: 1736-1764.

Taiz, L., and Zieger, E. 2002. Petal abscission in rose flowers: Effects of water potential, light intensity and light quality. Annals of Botany, 78: 619-623.

Zou, C.Y. and Liu, Y. 2010. Research advances in Dendrobium research in China. J. Anhui Agr., Sci. 38:61646166.

\section{How to cite this article:}

Punam Saikia, Pradip Mahanta and Rajib Lusan Deka. 2019. Correlation Studies of Growth and Flowering of Dendrobium cv. Sonia with Microclimatic Variables in Different Protected Structures. Int.J.Curr.Microbiol.App.Sci. 8(04): 954-962.

doi: https://doi.org/10.20546/ijcmas.2019.804.110 